КАЛАМАН О. Б.

канд. екон. наук, доиент, дочент кафедри менеджменту і логістики,

Одеська начіональна академія харчових технологій

вул. Канатна, 112, м. Одеса, Україна, 65039

e-mail: kalaman.olga@gmail.com

ORCID: 0000-0001-5586-7654

\title{
СКРІБАНС В.
}

д-р екон. наук, асоиійований професор, с.н.с.,

Рижський технічний університет

вул. Калнииемс, 6, м. Рига, Латвія, LV-1658

e-mail:skriban@inbox.lv

ORCID: 0000-0002-3401-4860

\section{МАНДРИКІН Д. В.}

магістр, здобувач кафедри менеджменту і логістики,

Одеська начіональна академія харчових технологій

вул. Канатна, 112, м. Одеса, Україна, 65039

e-mail: currrsor@gmail.com

ORCID: 0000-0002-7229-5894

\section{МЕТОДОЛОГІЯ ФОРМУВАННЯ ПОКАЗНИКІВ ЕФЕКТИВНОСТІ СТРАТЕГІЧНИХ УПРАВЛІНСЬКИХ РІШЕНЬ НА ПРОМИСЛОВИХ ПІДПРИЕМСТВАХ}

Актуальність. Промисловість, як одна зі складових наџіональної економіки будь-якої країни, грає в ній одну з провідних ролей через те, що саме промисловістю створюється переважна частина валового внутрішнього продукту. Крім изього, провідна роль промисловості полягає в тому, щуо від ї̈ успішності залежать ступінь задоволення потреб суспільства у високоякісній продукиї, забезпеченні технічного переозброєння виробництва і його інтенсифікації. Сформовані складні фінансово-економічні умови в економіці країни поки не дозволили досягти істотних змін в напрямі стабілізації промислового виробництва, поліпшення галузевої структури і його сочіальної орієнтації. Для виробництва різних форм власності, щчо функціонує в ринкових умовах, істотне значення має, з одного боку, вироблення принципів і норм стратегічного управління, а з іншого - ̈̈х практичне використання з метою підвищення ефективності промислового виробництва. Саме виокремлення зазначених проблем дозволило окреслити напрям дослідження щеоо методології формування показників ефективності стратегічних управлінських рішень на промислових підприємствах.

Мета та завдання. Метою роботи є розробка та обгрунтування методології показників ефективності стратегічних управлінських рішень на промислових підприємствах. Досягнення поставленої мети дослідження зумовило формування та вирішення наступних завдань: дослідити систему основних показників ефективності діяльності підприсмства; сформувати методологічну основу стратегічних управлінських рішень.

Результати. У роботі розроблена та обгрунтована система основних показників ефективності діяльності підприємства, який передбачає розрахунок наступних показників рентабельності: виробництва продукиії, продажів, активів, власного капіталу, виробничих фондів, персоналу, інвестованого капіталу та ін. Встановлено, щзо ефективність це є сума двох чинників: різниці між результатами і витратами, яка свідчить про позитивне сальдо (тобто про користь, яка принесена людськими зусиллями), $і$ здатності иієї різниці задовольняти реальні життєві потреби суспільства (людей). Показано, щчо джерелами стратегічних ідей при централізованому прийнятті рішень є вищий рівень управління (вищий менеджмент) через те, щэо саме там зосереджується інформація, а також центральні служби і керівники виробничих відділень.

Висновки. Одержані результати дослідження дозволяють систематизувати інформацію, отриману иляхом розрахунку показників ефективності діяльності підприємств та формалізувати процес прийняття управлінських рімень; удосконалити наукове забезпечення процесу реалізації стратегічних змін на підприємстві шляхом використання чотирьохступеневої моделі «поступового (еволючійного) наростання змін».

Ключові слова: ефективність, стратегічні рімення, методологія, промислові підприємства, показники ефективності, стратегічні ідеї. 
KALAMAN O. B.

PhD in Economics, Associate Professor of the Department of Management and Logistics,

Odessa National Academy of Food Technologies

Kanatnaya street, 112, s. Odessa, Ukraine, 65039

e-mail:kalaman.olga@gmail.com

ORCID: 0000-0001-5586-7654

SKRIBANS V.

Dr. Sc. (Economics), Associate Professor, Senior Research

Riga Technical University

6 Kalnciema str. Riga LV-1658 Latvia

e-mail:skriban@inbox.lv

ORCID: 0000-0002-3401-4860

MANDRYKIN D. V.

Applicant for the Department of Management and Logistics,

Odessa National Academy of Food Technologies

st. Kanatnaya, 112, s. Odessa, Ukraine, 65039

e-mail: currrsor@gmail.com

ORCID: 0000-0002-7229-5894

\section{METHODOLOGY FOR THE FORMATION OF INDICATORS OF THE EFFECTIVENESS OF STRATEGIC MANAGEMENT DECISIONS IN INDUSTRIAL ENTERPRISES}

Topicality. Industry, as one of the components of the national economy of any country, plays one of the leading roles in it due to the fact that it is industry that creates a large part of the GDP. In addition, the leading role of industry lies in the fact that the degree of satisfaction of society's needs for high-quality products, ensuring the technical reequipment of production and its intensification depends on its success. Formed difficult financial and economic conditions in the country's economy have not yet made it possible to achieve significant changes in the direction of stabilizing industrial production, improving the sectoral structure and its social orientation. For the production of various forms of ownership, functioning in market conditions, it is essential, on the one hand, to develop principles and norms of strategic management, and on the other, to their practical use in order to increase the efficiency of industrial production. It is the isolation of these problems that made it possible to determine the direction of research on the methodology for the formation of indicators of the effectiveness of management decisions at industrial enterprises.

Aim and tasks. The aim of the work is to develop and substantiate a methodology for indicators of the effectiveness of management decisions at industrial enterprises. Achievement of the set research goal led to the formation and resolution of the following tasks: to study the system of main indicators of the enterprise's performance; to form a methodological basis for management decisions.

Research results. The work developed and substantiated a system of main indicators of the enterprise's performance, which provides for the calculation of the following profitability indicators: production, sales, assets, equity, production assets, personnel, invested capital, etc. It has been established that efficiency is the sum of two factors: the difference between results and costs, which indicates a positive balance (i.e., the benefits that are brought by human efforts), and the ability of this difference to meet the real vital needs of society (people). It is shown that the sources of strategic ideas in centralized decision-making are a high level of management (top management) due to the fact that it is there that information is concentrated, as well as central services and heads of production departments.

Conclusion. The obtained results of the study make it possible to systematize the information obtained by calculating the indicators of the efficiency of enterprises and to formalize the process of making managerial decisions; to improve the scientific support of the process of implementation of strategic changes at the enterprise by using the four-stage model of "gradual (evolutionary) growth of changes".

Keywords: efficiency, strategic decisions, methodology, industrial enterprises, performance indicators, strategic ideas.

Постановка проблеми та ї̈ зв'язок з важливими науковими та практичними завданнями. У вітчизняній промисловості кількість і складність вирішуваних завдань безперервно ростуть. У зв'язку з цим система управління промисловим підприємством повинна адекватно реагувати на всі зміни, що відбуваються в зовнішньому і внутрішньому середовищі підприємства, і отримувати при цьому нові якості. Все це стає можливим лише на основі впровадження в практику сучасних принципів і методів стратегічного управління, а також способів оцінки їх ефективності. Однак проведений вище аналіз дозволяє зробити висновок, що накопичилося багато невирішених питань, що не дає промисловим підприємствам можливість більш високими темпами змінювати напрями 
діяльності в області структури виробництва, розширення ринків збуту продукції, тощо.

Слід зазначити, що наявні матеріальні, трудові і фінансові ресурси використовуються найчастіше недостатньо ефективно саме в силу відсутності у більшості промислових підприємств обгрунтованої концепції стратегічного управління. Використання промисловими підприємствами в практичній діяльності інструментів і методів стратегічного управління дозволило б забезпечити стійке зростання виробництва товарів і послуг і підвищити питому вагу конкурентоспроможної продукції, тобто досягти основних цілей підприємства.

Аналіз останніх публікацій по проблемі. Серед зарубіжних вчених-економістів, які здійснили істотний внесок у розробку наукових основ стратегічного управління, слід виділити дослідження таких авторів як: Р. Акофф, І. Ансофф, С. Бір, Р. Брейлі, П. Друкер, Б. Карлоф, У. Кінг, Д. Клиланд, Ф. Котлер, Р. Піндайк, М. Портер, Г. Саймон, А. Стрікленд, А. Томпсон, Д. Хан і ін. У вітчизняній економічній науці теорія стратегічного управління знайшла відображення в роботах Б. В. Буркинського [1], В. А. Винокурова, О. С. Віханського, І. М. Герчикова, В. Я. Горфинкеля, А. П. Градова, І. І. Грузнова, Г. В. Карпінська [2-3], Г. Б. Клейнера, О. І. Лайко, Б. Г. Литвак, В. В. Лукащук, Ю. А. Маленкова, В. Д. Маркової, А. Н. Петрова, Н. А. Савельєвої, А. В. Тебекіна, Е. А. Уткіна, Р. А. Фатхутдінова, Л. С. Шеховцева, Н. Л. Шлафман і інших.

Виділення невирішених раніше частин загальної проблеми. Проте проблеми, пов'язані із розробкою та обгрунтуванням методології формування показників ефективності стратегічних управлінських рішень на промислових підприємствах, залишаються досі недостатньо вирішеними.

Формулювання цілей дослідження(постановка завдання). Метою роботи $\epsilon$ розробка та обгрунтування методології показників ефективності стратегічних управлінських рішень на промислових підприємствах. Досягнення поставленої мети дослідження зумовило формування та вирішення наступних завдань:

- дослідити систему основних показників ефективності діяльності підприємства;

- сформувати методологічну основу стратегічних управлінських рішень.

Виклад основних результатів та їх обгрунтування. Ефективність у досить широкому сенсі можна розуміти як синтез існуючого результату діяльності і тієї користі (потенціалу), яку він несе в собі. За своєю суттю ефективність це $є$ сума двох чинників: різниці між результатами і витратами, яка свідчить про позитивне сальдо (тобто про користь, яка принесена людськими зусиллями), і здатності цієї різниці задовольняти реальні життєві потреби суспільства (людей). Так, наприклад, під економічною ефективністю суб'єктів управління розуміється зіставлення результатів діяльності 3 загальними витратами ресурсів. Якщо говорити в цілому про ефективність діяльності підприємства, то вона пов'язана з комплексною оцінкою ефективності бізнесу і оцінкою вартості бізнесу [4].

Однією $з$ основних цілей діяльності будь-якого підприємства є прибуток, який виступає як один 3 результатів його діяльності. Прибуток має стимулюючу функцію, будучи одним 3 джерел поповнення фінансових ресурсів підприємства, які можуть бути спрямовані як на виробничий, так і на соціальний розвиток підприємства. Крім того прибуток підприємств, виступаючи в якості бази оподаткування, $є$ для держави одним з найважливіших джерел формування бюджетів різних рівнів. Тому державі необхідно проводити таку економічну політику, яка була б сприятливою для ведення господарської діяльності і забезпечувала високу економічну ефективність виробництва, орієнтуючи підприємство на максимальне отримання прибутку [5].

Щоб створити прибуток, підприємство повинне стежити за середовищем, в якому воно функціонує. Саме у навколишньому середовищі керівництво підприємства підшукує спільну мету, на досягнення якої і будуть спрямовані всі сили і ресурси підприємства. Довгострокова мета має горизонт планування приблизно п'ять років. Короткострокова мета в більшості випадків представляє один з планів підприємства, який слід завершити в межах року. Основними шляхами збільшення прибутку на підприємстві можуть бути: збільшення обсягу продукції, що випускається, диверсифікація виробництва, розширення ринку продажів, зниження собівартості продукції, інше [6].

Прибуток, як і обсяг продукції, що випускається (реалізується), будучи найважливішим економічним показником, сам по собі, як показник абсолютний, не може виступати в якості критерію ефективності виробничо-господарської діяльності підприємства. Для його визначення використовують різні показники рентабельності (рис. 1), які, будучи відносними показниками, $\epsilon$ зіставленням прибутку, як результату діяльності підприємства, з витратами (ресурсами), які цей результат забезпечили [7].

Фактично показники рентабельності $\epsilon$ стратегічними показниками для підприємства. Стратегічні показники - це показники, що включаються в стратегію у вигляді орієнтирів, результатів, установок і інших кількісних і якісних показників. Частина стратегічних показників є критеріями 
(критеріальними показниками), на основі яких здійснюється вибір керівника на користь того чи іншого управлінського рішення [8]. Слід зазначити, що стратегічні показники, в тому числі і критерії вибору, дозволяють розробити для підприємства правила прийняття стратегічних рішень.

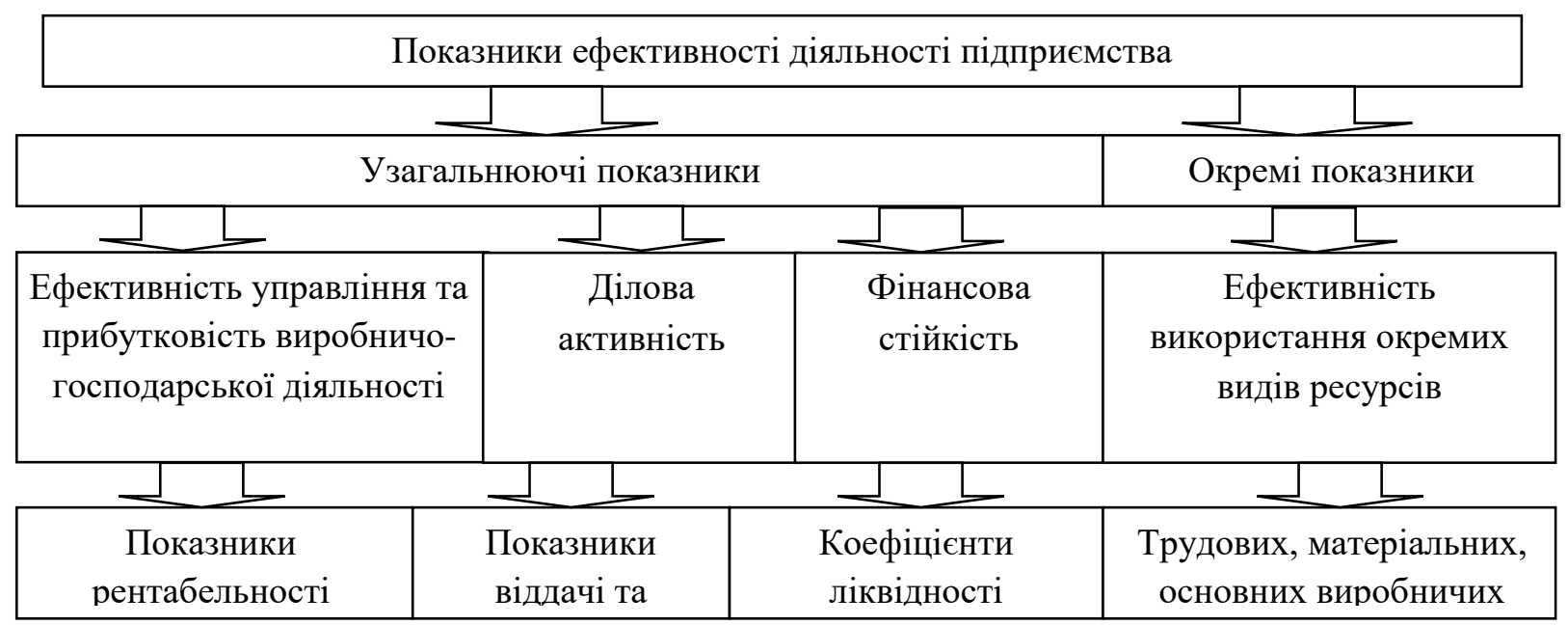

Рис. 1. Система основних показників ефективності діяльності підприємства

Джерело: сформовано автором

При аналізі ефективності роботи підприємства найчастіше розраховують наступні показники рентабельності: виробництва продукції, продажів, активів, власного капіталу, виробничих фондів, персоналу, інвестованого капіталу та ін.

Рентабельність виробництва показує, який прибуток підприємство отримує з кожної гривні, витраченої на виробництво продукції. Розраховується як відношення чистого прибутку (прибутку після вирахування податків) до витрат на виробництво:

де $\mathrm{REN}_{\text {proiz }}$ - показник рентабельності виробництва;

$$
\mathrm{REN}_{\text {proiz }}=\mathrm{PRIB}_{\mathrm{th}} / \mathrm{COS}_{\text {proiz }}
$$

$\mathrm{PRIB}_{\mathrm{th}}$ - величина чистого прибутку;

$\operatorname{COS}_{\text {proiz }}$ - витрати на виробництво.

Цей показник може розраховуватися як в цілому по підприємству, так і по його окремих підрозділах або видах продукції.

Рентабельність продажів показує частку прибутку в кожній гривні виручки. Зазвичай розраховується як відношення чистого прибуток (прибуток після вирахування податків) за певний період до вираженого в грошових коштах обсягу продажів (виручки) за той же період:

де $\mathrm{REN}_{\mathrm{pr}}$ - показник рентабельності продажів;

$$
\mathrm{REN}_{\mathrm{pr}}=\mathrm{PRIB}_{\mathrm{th}} / \mathrm{CAP}_{\mathrm{vp}}
$$

$\mathrm{PRIB}_{\mathrm{th}}$ - величина чистого прибутку;

$\mathrm{CAP}_{\mathrm{vp}}$ - обсяг продажів (виручка).

Рентабельність активів показує, яку величину чистого прибутку приносить кожна гривня активів, що є в розпорядженні підприємства. Розраховується як відношення чистого прибутку до активів підприємства:

$$
\mathrm{ROA}=\mathrm{PRIB}_{\text {th }} / \mathrm{AS}
$$

де ROA - показник рентабельності активів;

$\mathrm{PRIB}_{\mathrm{th}}$ - величина чистого прибутку;

$\mathrm{AS}$ - величина активів.

Як правило, для проведення розрахунків використовується середньорічна величина активів підприємства, тобто сума активів на початок і на кінець року, поділена навпіл.

Рентабельність власного (акціонерного) капіталу показує, який прибуток приносить кожна гривня, вкладена в підприємство його власниками. Розраховується як відношення чистого прибутку до власного капіталу:

$$
\mathrm{ROE}=\mathrm{PRIB}_{\text {th }} / \mathrm{CAP}_{\mathrm{ow}}
$$

де ROE - показник рентабельності власного (акціонерного) капіталу;

$\mathrm{PRIB}_{\mathrm{th}}$ - величина чистого прибутку; 
$\mathrm{CAP}_{\text {оw }}$ - власний капітал.

Відправним пунктом для аналізу ефективності роботи підприємства може служити порівняння рентабельності власного капіталу 3 величиною банківської ставки. Якщо даний коефіцієнт рентабельності нижче або дорівнює прибутковості банківського депозиту, то діяльність підприємства не $\epsilon$ ефективною. Коефіцієнт рентабельності власного капіталу часто застосовується для порівняння однотипних підприємств, що відносяться до однієї галузі. Він $є$ найважливішим для оцінки інвестиційної привабливості підприємства в довгостроковій перспективі.

Рентабельність основних виробничих фондів (фондорентабельність) показує, який прибуток підприємство отримує з кожної гривні вартості основних виробничих фондів. Розраховується, як відношення чистого прибутку підприємства до середньої вартості основних виробничих фондів:

$$
\mathrm{REN}_{\mathrm{pf}}=\mathrm{PRIB}_{\mathrm{th}} / \mathrm{PFCA}
$$

де $\mathrm{REN}_{\mathrm{pf}}$ - показник рентабельності основних виробничих фондів;

$\mathrm{PRIB}_{\text {th }}$ - величина чистого прибутку;

PFCA - вартість основних виробничих фондів.

Рентабельність персоналу (ROL) показує ефективність використання трудових ресурсів на підприємстві. Розраховується як відношення чистого прибутку до середньооблікової чисельності персоналу:

$$
\mathrm{ROL}=\mathrm{PRIB}_{\mathrm{th}} / \mathrm{ASN}
$$

де ROL - показник рентабельності персоналу;

$\mathrm{PRIB}_{\text {th }}$ - величина чистого прибутку;

ASN - середньооблікова чисельність персоналу.

Рентабельність інвестованого (перманентного) капіталу (ROIC) показує ефективність капіталу, вкладеного в підприємство на тривалий термін. Розраховується як відношення чистого прибутку до середнього за період розміру власного і довгострокового позикового капіталу:

$$
\mathrm{ROIC}=\mathrm{PRIB}_{\text {th }} /\left(\mathrm{CAP}_{\mathrm{ow}}+\mathrm{CAP}_{\mathrm{l}}\right)
$$

де ROIC - показник рентабельності інвестованого (перманентного) капіталу;

$\mathrm{PRIB}_{\mathrm{th}}$ - величина чистого прибутку;

$\mathrm{CAP}_{\text {ow }}$ - власний капітал;

$\mathrm{CAP}_{1}$ - довгостроковий позиковий капітал.

Як правило, розраховані показники рентабельності зіставляють з плановими, з відповідними показниками попередніх періодів або з показниками рентабельності інших підприємств даної галузі.

В умовах невизначеності ринкового середовища, коли необхідно приймати господарські рішення, потрібен обгрунтований з економічної точки зору вибір відповідних методів і механізмів управління та їх оцінка. Це пов'язано $з$ тим, що сьогодні багато ніш господарювання, в яких працюють промислові підприємства, характеризуються підвищеним ризиком, обумовленим відсутністю інформації про поведінку споживачів, позиції конкурентів, тощо $[9,10]$.

У збутовій діяльності промислових підприємств України так само існує безліч проблем. Керівники підприємств, які виробляють кінцеву або проміжну продукцію, відчувають обмеження 3 боку платоспроможного попиту населення і підприємств-споживачів. Питання збуту увійшли в сферу безпосереднього контролю керівництва підприємств. Зараз майже всі підприємства усвідомили важливість збутової програми. Більшості 3 них доводиться вирішувати тактичні питання, так як багато підприємств стикаються з проблемою затоварення складів своєю продукцією і різкого падіння попиту на неї. Якщо продукція, що випускається, $є$ виробничого призначення, то в деяких випадках підприємства розвивають і підрозділи, які споживають цю продукцію. Перебудовуючи свій асортимент, підприємства стали заздалегідь прогнозувати збут і знаходити споживачів своєї продукції. В системі промислового виробництва при виборі споживачів враховуються: безпосередній контакт і зв'язок з кінцевими споживачами, а також їх платоспроможність.

Актуальним для підприємств став пошук нових споживачів і освоєння нових ринків. Сьогодні отримують свій розвиток взаємини підприємств з новими комерційними структурами, які займаються реалізацією частини продукції підприємства, а інша іiі частина збувається за старими каналами. Однією з тактик забезпечення збуту продукції промислового підприємства в умовах, коли внутрішній платоспроможний попит на продукцію обмежений, став вихід на міжнародні ринки. Однак це можливо тільки для промислових підприємств 3 високим рівнем технології виробництва, що забезпечує конкурентоспроможність їх товарів.

Стратегічне управління, при використанні якого розробляється місія підприємства, його цілі, функції та завдання в довгостроковій перспективі, грає першорядну роль в розвитку промислового 
виробництва, і від якості стратегічних рішень залежить ефективність і результативність бізнеспроцесів, що протікають.

Основу стратегічного управління складають стратегічні рішення. Тому стратегічне управління має являти собою набір таких управлінських рішень, які орієнтовані на реалізацію стратегії підприємства, на його довгостроковий розвиток, але при цьому є як би базою для прийняття оперативних, короткострокових рішень, грунтуючись на врахуванні неконтрольованих факторів зовнішнього і внутрішнього середовища $[11,12]$.

Стратегічними рішеннями стосовно промислових підприємств будуть рішення, пов'язані, наприклад, 3 розробкою і впровадженням інновацій, нових видів продукції, перспективних технологій організації виробничих процесів і, в цілому, пов'язані з реструктуризацією виробничої системи, оптимізацією організаційної структури, більш ефективним використанням матеріальнотехнічних ресурсів, підвищенням організаційно-технологічної та організаційно-економічної надійності виробничих процесів; а так само рішення, пов'язані 3 виходом на нові ринки, диверсифікацією, придбанням, злиттям або укрупненням підприємства [13].

Методологічну основу стратегічних управлінських рішень зумовлюють наступні стилі і принципи управління:

- управління на основі контролю: першочерговим є застосування фінансового контролю 3 метою стабільного розвитку підприємства на перспективу;

- управління на основі екстраполяції: рішення приймаються з урахуванням тієї ж динаміки, тенденцій розвитку, як і в звітному періоді, на основі цільового управління і довгострокового планування. При цьому передбачається складання i аналіз поточних бюджетів, бюджетів капіталовкладень та ін.;

- управління на основі розробки принципово нових стратегій: передбачає прийняття нових стилів і принципів управління в разі очевидності появи нових орієнтирів, тенденцій розвитку підприємства, а також при виробленні нових стратегічних позицій і стратегічних планів по періодах;

- управління на основі прийняття оперативних рішень. Даний спосіб управління базується на основі ранжирування стратегічних цілей розвитку і застосовується при виникненні непередбачуваних ситуацій і тенденцій розвитку.

Джерелами стратегічних ідей при централізованому прийнятті рішень $є$ вищий рівень управління (вищий менеджмент) через те, що саме там зосереджується інформація, а також центральні служби і керівники виробничих відділень. Виявлення стратегічних проблем і вироблення стратегічних ідей здійснюються «зверху вниз», тобто вищим рівнем управління у взаємодії 3 організаційно-управлінським і плановим апаратом, який виконує ключову роль в зборі та аналізі інформації. Вищим керівництвом підприємства виробляється загальна стратегія, розподіляється відповідальність між виконавцями і координується проведення заходів з реалізації стратегічних завдань.

Прийняття стратегічних рішень децентралізовано означає, що стратегічні напрями в підрозділах розробляються керівниками підрозділів. Інформація зосереджується в самих структурних підрозділах, які визначають свої цілі, стратегії, плани, але в рамках і з урахуванням загальної стратегії підприємства, що формується на вищому рівні управління.

Прийняття стратегічних рішень у взаємодії означає, що стратегія розробляється в ході взаємодії між вищим керівництвом, апаратом планування і структурними підрозділами. Основні цілі і напрями при цьому визначаються вищим керівництвом, стратегія ж формується в результаті взаємодії по вертикалі. Структурні підрозділи, хоча і виконують розпорядження вищого керівництва, але в той же час самостійно формують для себе стратегію і оперативні плани. У сучасних умовах розвитку економіки і промислового виробництва зокрема, підхід до розробки стратегії все більше набуває відкритості, тобто передбачає доступність підлеглим, які беруть участь в її реалізації [9].

При реалізації стратегічних змін на підприємстві, на наш погляд, досить успішно, може використовуватися наступна чотирьохступенева модель так званого «поступового (еволюційного) наростання змін» (рис. 2) [11].

Стратегічним управлінням на підприємстві займаються менеджери, головним завданням яких, крім розробки самої стратегії розвитку, є організація роботи колективу. Роботу на підприємстві слід організовувати 3 таким розрахунком, щоб вона максимально відповідала потребам колективу, дозволяла активізувати його роботу і підвищувала його ефективність $[8,12]$. Беручи будь-які управлінські рішення, необхідно мати на увазі, що вони повинні сприяти не тільки отриманню високої рентабельності підприємства, але і повинні бути націлені на вирішення проблем соціального 
характеру своїх співробітників, а також споживачів, заради яких підприємство існує, і задоволення потреб яких реально обумовлює необхідність його функціонування. Будь-яке прийняте рішення має в тривалій перспективі свідчити про економічну доцільність виробництва, має підтримувати його стратегію і його діяльність. Таким чином, забезпечення існування підприємства на ринку можна вважати одним із головних завдань стратегічного управління.

Висновки та перспективи подальших досліджень. У вітчизняній промисловості кількість і складність вирішуваних завдань безперервно ростуть. У зв'язку 3 цим система управління промисловим підприємством повинна адекватно реагувати на всі зміни, що відбуваються в зовнішньому і внутрішньому середовищі підприємства, і отримувати

\section{ПЕРШИЙ ЕТАП}

відбувається створення команди, що складається із співробітників, які володіють знаннями та досвідом, переконаними в необхідності змін на підприємстві

\section{ДРУГИЙ ЕТАП}

спрощуються завдання підприємства, тобто концентрація його ресурсів здійснюється лише на найважливіших стратегічних напрямах. При цьому відсікаються окремі види діяльності, які споживають значні ресурси підприємства, але які не є ключовими при реалізації стратегічних завдань

ТРЕТІЙ ЕТАП

полягає в створенні нових ключових переваг підприємства i пов'язаний 3 формулюванням нових завдань його діяльності. Дані завдання повинні вирішуватися поступово, так як $є$ фактично експериментальними для підприємства $\mathrm{i}$ тому пов'язані з певним ризиком

ЧЕТВЕРТИЙ ЕТАП

необхідно зберегти здійснені перетворення, закріпити досягнуті підприємством успіхи, шляхом створення надійних важелів управління ними, в якості яких можуть виступати створені нові структурні підрозділи, системи стимулювання, тощо

Рис. 2. Чотирьохступенева модель «поступового (еволюційного) наростання змін» Джерело: сформовано автором

при цьому нові якості. Все це стає можливим лише на основі впровадження в практику сучасних принципів і методів стратегічного управління, а також способів оцінки їх ефективності. Однак проведений вище аналіз дозволяє зробити висновок, що накопичилося багато невирішених питань, що не дає промисловим підприємствам можливість більш високими темпами змінювати напрями діяльності в області структури виробництва, розширення ринків збуту продукції, тощо.

Таким чином, метою дослідження, яка полягала у розробці та обгрунтуванні методології показників ефективності стратегічних управлінських рішень на промислових підприємствах, була досягнута, а сформовані завдання виконані. Вони полягали у дослідженні системи основних показників ефективності діяльності підприємства; формуванні методологічної основи стратегічних управлінських рішень. Слід зазначити, що наявні матеріальні, трудові і фінансові ресурси використовуються найчастіше недостатньо ефективно саме в силу відсутності у більшості промислових підприємств обгрунтованої концепції стратегічного управління. Використання промисловими підприємствами в практичній діяльності інструментів і методів стратегічного управління дозволило б забезпечити стійке зростання виробництва товарів і послуг і підвищити питому вагу конкурентоспроможної продукції, тобто досягти основних цілей підприємства.

\section{ЛІТЕРАТУРА}

1. Чорна М. В., Дядін А. С. Ефективність підприємницької діяльності суб’єктів господарювання в роздрібній торгівлі в конкурентному середовищі. Актуальні проблеми та напрями розвитку потенціалу соціально-економічних систем в умовах конкуренції: монографія / за заг. ред. д-ра екон. наук, проф. Л. Л. Калініченко. Харків: ФОП Панов А. М., Видав. ТОВ «В справі», 2017. С. 154-159.

2. Щербань О. Д., Коновал А. В. Механізм формування фінансових ресурсів підприємств. 
Економіка і суспільство. 2018. Вип. 16. С. 554-559.

3. Маркетингові дослідження сталого розвитку в умовах глобальних викликів : монографія / за заг. ред. проф. М. М. Новікової; [Новікова М. М., Боровик М. В., Бурмака Т. М. та ін.]; Харків. нац. ун-т міськ. госп-ва ім. О. М. Бекетова. Харків : Видавництво «Точка», 2018. 240 с.

4. Савицька О. М., Салабай В. О. Ефективність діяльності та управління підприємством: особливості використання теорії, методологій та результативності аналітичних досліджень. Ефективна економіка. 2019. № 6. DOI: 10.32702/2307-2105-2019.6.55.

5. Швиданенко Г. О., Бойченко К. С. Розвиток підприємства: стратегічні наміри, ризики та ефективність: колективна монографія. К.: КНЕУ. 2015. 231 с.

6. Поплавська Ж. В., Михальчишин Н. Л., Данилович-Кропивницька М. Л., Гошовська О. В., Комаринець С. О. Сучасні форми конкурентної взаємодії суб'єктів господарювання: монографія / за заг. ред. Ж. В. Поплавської. Львів: ТОВ «Галицька видавнича спілка», 2019. 201 с.

7. Каламан О. Б. Управління стратегією розвитку виноробних підприємств: монографія. Одеса: Друкарський дім, Друк Південь, 2020.391 с.

8. Каламан О. Б. Управління стратегічним розвитком сучасних виноробних підприємств: теоретичний аспект. Механізм управління формуванням стратегій випереджаючого інноваційного розвитку промислових підприємств: монографія / за заг. ред. к.е.н., доц. Н. С. Ілляшенко. Суми: Триторія, 2019. С. 156-169.

9. Лайко О. І., Уманець Т. В., Шлафман Н. Л. Стратегічні напрямки здійснення податкового регулювання економічного розвитку в умовах реформ. Економічні інновачії. 2021. Т.23. Вип. 1 (78). C.115-125.

10. Буркинський Б. В., Лайко О. І., Шлафман Н. Л. Стратегічні напрямки підвищення продуктивності підприємницької діяльності в Україні. Економічні інноваиії. 2020. Т.22. Вип. 4 (77). С.7-18.

11. Маслій Н. Д. Інтеграційні форми розвитку підприємств: теоретичні аспекти та практичні підходи : монографія. Одеса: Одеський національний університет імені I. І. Мечникова, 2018. 306 с.

12. Маслій Н. Д. Методологічні основи створення кластерів в галузі зв’язку. Інноваційна економіка. 2013. № 4 [42]. С. $67-70$.

13. Безпарточний М. Г. Використання кластерного аналізу при оцінці ефективності діяльності торговельних підприємств. Торгівля, комериія, підприємництво : збірник наукових праць / редакц. кол.: Апопій В. В., Куцик П. О., Шевчук В. О. та ін. Львів: Львівська комерційна академія, 2014. Вип. 17. C. $24-27$.

\section{REFERENCES}

1. Chorna, M. V., \& Diadin, A. S. (2017). Efektyvnist pidpryiemnytskoi diialnosti subiektiv hospodariuvannia $\mathrm{v}$ rozdribnii torhivli $\mathrm{v}$ konkurentnomu seredovyshchi [Efficiency of acceptance of government subordinates in the development of trade in a competitive environment]. Aktualni problemy ta napriamy rozvytku potentsialu sotsialno-ekonomichnykh system v umovakh konkurentsii - Actual problems that directly develop the potential of social and economic systems in the minds of competition (pp. 154-159). Kharkiv: FOP Panov A. M., Vydav. TOV «V spravi» [in Ukrainian].

2. Shcherban, O. D., \& Konoval, A. V. (2018). Mekhanizm formuvannia finansovykh resursiv pidpryiemstv [Mechanism of forming financial resources of enterprises]. Ekonomika i suspilstvo-Economy and suspension, 16, 554-559. [in Ukrainian].

3. Novikova, M. M. (Ed.) (2018). Marketynhovi doslidzhennia staloho rozvytku v umovakh hlobalnykh vyklykiv [Marketing to the latest development in the minds of global victories]. Kharkiv : Vydavnytstvo "Tochka" [in Ukrainian].

4. Savytska, O. M., \& Salabai, V. O. (2019). Efektyvnist diialnosti ta upravlinnia pidpryiemstvom: osoblyvosti vykorystannia teorii, metodolohii ta rezultatyvnosti analitychnykh doslidzhen [Effectiveness and management of the enterprise: special features of the theory, methodology and effectiveness of analytical messages]. Efektyvna ekonomika - Economics is effective, 6. DOI: 10.32702/2307-2105-2019.6.55. [in Ukrainian].

5. Shvydanenko, H. O., \& Boichenko, K. S. (2015). Rozvytok pidpryiemstva: stratehichni namiry, ryzyky ta efektyvnist [Development of the enterprise: strategic namiri, riziki and efficiency]. Kiev: KNEU [in Ukrainian].

6. Poplavska, Zh. V., Mykhalchyshyn, N. L., Danylovych-Kropyvnytska, M. L., Hoshovska, O. V., \& Komarynets, S. O. (2019). Suchasni formy konkurentnoi vzaiemodii subiektiv hospodariuvannia [Modern 
forms of competitive interaction of business entities]. Lviv: TOV "Galitska vidavnycha spilka" [in Ukrainian].

7. Kalaman, O. B. (2020). Upravlinnia stratehiieiu rozvytku vynorobnykh pidpryiemstv [Management of strategic development of wineries]. Odesa: Drukarskyi dim, Druk Pivden [in Ukrainian].

8. Kalaman, O. B. (2019). Upravlinnia stratehichnym rozvytkom suchasnykh vynorobnykh pidpryiemstv: teoretychnyi aspekt [Management of strategic development of wineries: theoretical aspect]. Mekhanizm upravlinnia formuvanniam stratehii vyperedzhaiuchoho innovatsiinoho rozvytku promyslovykh pidpryiemstv - Mechanism of managing the formulation of strategies for the forward-looking innovation development of industrial enterprises (pp. 156-169). Sumy: Trytoriia [in Ukrainian].

9. Layko, O. I., Umanets', T. V., Shlafman, N. L. (2021). Stratehichni napryamky zdiysnennya podatkovoho rehulyuvannya ekonomichnoho rozvytku v umovakh reform [Strategic direct development of tax regulation of economic development in the minds of reforms]. Ekonomichni innovatsiyi, 23, 1 (78), 115125[in Ukrainian].

10. Burkyns'kyy, B. V., Layko, O. I., Shlafman, N. L. (2020). Stratehichni napryamky pidvyshchennya produktyvnosti pidpryyemnyts'koyi diyal'nosti v Ukrayini [Strategic directly to improve the productivity of industrial activity in Ukraine]. Ekonomichni innovatsiyi, 22, 4 (77), 7-18 [in Ukrainian].

11. Masliy, N. D. (2018). Intehratsiyni formy rozvytku pidpryyemstv: teoretychni aspekty ta praktychni pidkhody [Integration form development of enterprises: theoretical aspects and practical approaches]. Odesa: Odes'kyy natsional'nyy universytet imeni I. I. Mechnykova [in Ukrainian].

12. Masliy, N. D. (2013). Metodolohichni osnovy stvorennya klasteriv v haluzi zv"yazku [Methodological bases of cluster formation in the hallucination]. Innovatsiyna ekonomika, 4 [42], 67-70 [in Ukrainian].

13. Bezpartochnyy, M. H. (2014). Vykorystannya klasternoho analizu pry otsintsi efektyvnosti diyal'nosti torhovel'nykh pidpryyemstv [Vikoristannya cluster analysis in the assessment of the efficiency of trade enterprises]. Torhivlya, komertsiya, pidpryyemnytstvo, 17, 24-27 [in Ukrainian]. 